\title{
AUTHENTICITEIT, EEN GELOOFWAARDIG BEGRIP?
}

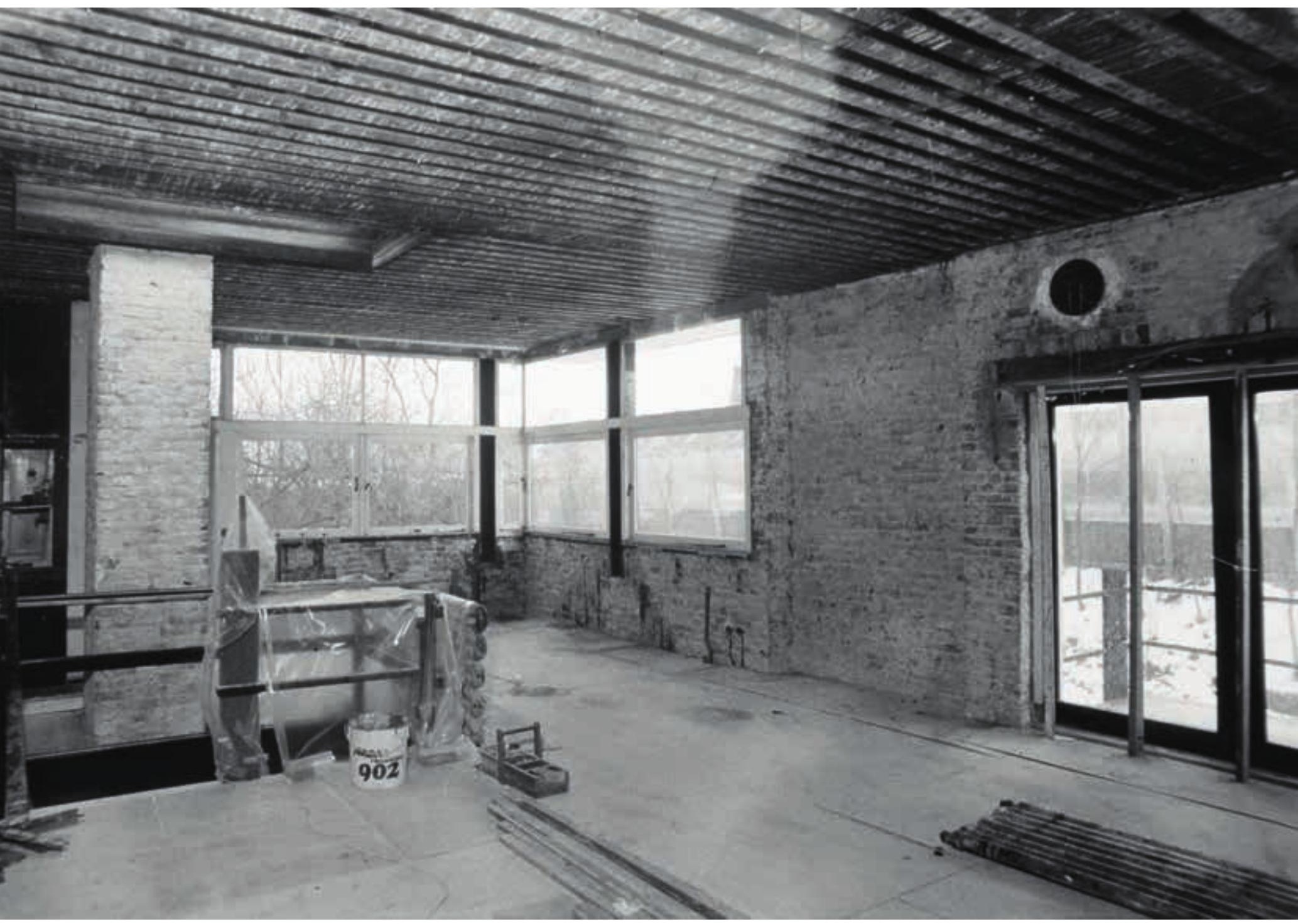

\ 1. Rietveld Schröderhuis, Utrecht, interieur van de bovenverdieping tijdens de restauratie in 1985-1986. Architect Bertus Mulder heeft de nog aanwezige afwerklagen van plafond en muren volledig verwijderd (Bertus Mulder archief, Centraal Museum Utrecht)
Ruim veertig jaar geleden, in 1978, werd een nummer van het Bulletin клов gewijd aan de problematiek van de architectuurrestauratie. De bijdragen weerspiegelen de standpunten van de auteurs over restauratiefilosofie en -theorie en het is opvallend dat het begrip authenticiteit toen al centraal stond in het debat. Gekoppeld aan een ander begrip, de echtheidswaarde, passeren 'materiële echtheid van de historische substantie', 'authenticiteit van vorm', 'afwerking', maar ook 'proportie', 'lichtval' en zelfs al 'een stuk authentieke sfeer' de revue. ${ }^{1}$ \begin{tabular}{l} 
D \\
D \\
D \\
$\bar{Z}$ \\
D \\
v \\
U \\
\hline$\vec{U}$
\end{tabular} 
ontwerp; materialen en substantie; gebruik en functie; tradities, technieken en managementsystemen; locatie en omgeving; taal en andere vormen van 'intangible heritage'; geest en gevoel en andere interne en externe factoren.

Hiermee leggen de Guidelines een directe link naar The Nara Document on Authenticity (1994), waarin de beoordeling van authenticiteit is gebaseerd op eenzelfde rijke schakering aan bronnen. ${ }^{11}$ Het Nara Document werd opgesteld omdat de internationale erfgoedwereld een bredere basis wilde bieden voor de mondiale culturele diversiteit en de verscheidenheid in (de omgang met) erfgoed die deze met zich meebrengt. Daarom moeten we niet langer waarden of authenticiteit louter beoordelen op basis van vaststaande criteria, aldus artikel 11 van dit document. ${ }^{12}$ Zoals Gabri van Tussenbroek elders in dit nummer stelt, lijkt volgens de gedachtegang van de Conferentie van Nara echter alles mogelijk geworden, zolang de ouv vanuit de eigen cultuur maar geloofwaardig kan worden verteld..$^{13}$

\section{AUTHENTICITEIT EN DE MODERNE BEWEGING}

In 2019 schreef ik in een artikel over de restauraties van het Utrechtse Rietveld Schröderhuis (1924) dat 'Nara' de deur heeft opengezet voor veelzijdige en vaak persoonlijke interpretaties van erfgoed. ${ }^{14}$ De keuzes die architect Bertus Mulder (1929) in de jaren 1970 en 1980 bij de restauraties van het Rietveld Schröderhuis maakte, kwamen zeker niet overeen met de uitgangspunten van het op dat moment vigerende Charter van Venetië (1964). ${ }^{15}$ Tijdens de restauratie van het exterieur verwijderde Mulder grote delen van de bestaande gevelafwerking. Een decennium later ging hij in het interieur nog rigoureuzer te werk en stripte hij op de verdieping álle, nog grotendeels oorspronkelijke, afwerklagen (afb.1). Die materialiteit vond Gerrit Rietveld (1888-1964) juist belangrijk voor de ruimtelijke beleving. Maar Mulder achtte het materiaal secundair; voor hem stond het herscheppen van een oorspronkelijk ruimtebeeld voorop. Dat was niet zozeer gebaseerd op 'respect voor het originele materiaal en op authentieke documenten', zoals het Charter van Venetië dicteerde, maar weerspiegelde zijn eigen - authentieke? - interpretatie van Rietvelds principes. Hierdoor verdween niet alleen veel oorspronkelijk materiaal. Ook de historiciteit, de waarachtigheid en getuigenissen van de plek en het huis, in de betekenissen zoals Freek Schmidt die in dit nummer schetst, werden volledig buiten beschouwing gelaten. ${ }^{16}$

Toch hebben deze ingrijpende restauraties in 2000 de plaatsing van het Rietveld Schröderhuis op de Werelderfgoedlijst niet in de weg gestaan. Volgens het nominatiedossier heeft het huis de authenticiteit van het ontwerpconcept en de structuur behouden. Het monument voldoet volgens de motivatie 'in essentie' in alle opzichten aan de authenticiteitscriteria. ${ }^{17}$ Deze worden hier niet ontleend aan het document van Nara, maar zijn gebaseerd op vier aspecten van authenticiteit die in het bijzonder gelden voor gebouwen van de Moderne Beweging: authenticiteit van idee (het oorspronkelijk ontwerpconcept); van vorm, ruimtelijke organisatie en uiterlijk; van constructie en details, én - wonderlijk genoeg - authenticiteit van materialen.

Noor Mens beschrijft in dit nummer waarom de zorg voor het moderne erfgoed vanaf de jaren 1980 niet alleen vroeg om een verbreding van waarderingskaders, maar ook om oplossingen voor de omgang met de vaak povere materialiteit van dit erfgoed. ${ }^{18}$ Authenticiteit van materialen blijkt in deze praktijk niet zozeer te worden opgevat als authenticiteit van de bestaande historische substantie, maar verwijst impliciet naar de oorspronkelijke materialen en naar het ontwerp(concept). Restauratiearchitect Wessel de Jonge (1957) spreekt in dit verband van 'ontwerpauthenticiteit'. ${ }^{19}$ Monumenten van de Moderne Beweging worden in deze optiek dus anders 'authentiek' bevonden en anders behandeld dan monumenten uit voorgaande periodes.

De Jonge was vanaf 2000 coördinerend architect van de restauratie en herstructuring van de Rotterdamse Van Nellefabriek (1925-1931), ontworpen door J.A. Brinkman en L.C. van der Vlugt en herbestemd tot Van Nelle Design Factory (afb. 2). Sinds 2014 staat ook dit complex op de Werelderfgoedlijst. De voormalige fabriek voor koffie, thee en tabak geldt als goed voorbeeld van 'adaptive re-use', dat volgens het Unesco-nominatiedossier bij de herstructurering zijn materiële en immateriële authenticiteit heeft behouden. ${ }^{20}$ En deze komt volgens de auteurs van het dossier tot uitdrukking in elk van de uiteenlopende eigenschappen die hierboven al werden genoemd: vorm; ontwerp; materialen en substantie; gebruik en functie; (dag)licht; locatie en omgeving; tradities, techniek en managementsystemen; andere interne en externe factoren en andere vormen van immaterieel erfgoed. 'Also from a conceptual perspective, the integrity of the ensemble - and the related spirit of collectivity and creativity - forms the basis for the present use as Van Nelle Factory'; een mooie omschrijving van 'spirit en feeling' in het 'Statement of Authenticity'. ${ }^{21}$ Authentieker dan dit lijkt bijna niet mogelijk, hoewel het complex de nodige veranderingen en vernieuwingen heeft ondergaan.

\section{AUTHENTICITEIT ALS UITZONDERLIJK KWALITEITSKENMERK}

Wim Denslagen stelde tien jaar geleden in zijn artikel 'Authenticiteit en spiritualiteit' dat de veelheid aan betekenissen van authenticiteit, de vrijheid aan keuzes en het gebrek aan eenduidigheid kan leiden tot willekeur. Hij definieerde het kort en krachtig: 'Authen- 
the Implementation of the World Heritage Convention, II.E, WHC.19/01 10 July 2019, 26-29: whc.unesco.org/en/ guidelines/.

8 UNESCO 2019 (noot 7), 26.

9 S. Nijhuis, 'Landschappelijke authenticiteit. Het landschap als levend systeem, geschiedenis en ruimtelijke beleving', Bulletin КNOB 119 (2020) 4, 32-37.

10 UNESCO 2019 (noot 7), 27.

11 ICOMOs, The Nara Document on Authenticity (1994): icomos.org/charters/ nara-e.pdf.

12 ICOMOS 1994 (noot 11), 47.

13 G. van Tussenbroek, 'Reconstructie en verzet. Over materiële authenticiteit', Bulletin KNOB 119 (2020) 4, 10-15.

14 M.T. van Thoor, 'De restauraties van het Rietveld Schröderhuis. Een reflectie', Bulletin КNOB 118 (2019) 4, 15-31.

15 ICOMOs, International Charter for the Conservation and Restoration of Monuments and Sites (The Venice Charter), IInd International Congress of Architects and Technicians of Historic
Monuments, Venice 1964. Adopted by ICOMOs in 1965.

16 F. Schmidt, 'Waarachtige architectuur. Over authenticiteit en herbestemming, Bulletin КNOB 119 (2020) 4, 16-21.

17 R. de Jong, I. van Zijl en B. Mulder, Rietveld Schröderhuis, Utrecht/(Rietveld Schröder House, Utrecht) The Netherlands, Utrecht/Zeist 1999, 16-17: whc. unesco.org/uploads/nominations/965. pdf.

18 N. Mens, 'Vorm en context. Over de rol van authenticiteit bij het waarderen van modern erfgoed', Bulletin КNOB 119 (2020) 4, 44-50.

19 C. van Emstede, Waardestelling in de Nederlandse monumentenzorg 1981-20o9, proefschrift TU Delft, 2015, 232: books. bk.tudelft.nl/index.php/press/catalog/ book/45o. Zie ook: D. van den Heuvel e.a. (red.), The Challenge of Change. Dealing with the Legacy of the Modern Movement. Proceedings of the 1oth International DOсомомо Conference, Delft 2008; S. Stroux e.a. (red.), Reco.mo.mo. Hoe echt is namaak, hoe dierbaar is het origineel?, Delft 2011.

20 M. Kuipers en T. Knibbeler e.a., Van Nellefabriek Rotterdam, Nomination File. Nomination by the Kingdom of the Netherlands for Inscription on the Unesco World Heritage List, Rotterdam 2013: whc.unesco.org/uploads/nominations/1441.pdf.

21 Kuipers en Knibbeler e.a. 2013 (noot 20), 103-105, i.h.b. 104.

22 W. Denslagen, 'Authenticiteit en spiritualiteit', Bulletin KNOB 109 (2010) 4, 135140, i.h.b. 138.

23 A. Pereira Roders, WALL-E. Value. Conserve. Evolve, inaugurele rede $\mathrm{TU}$ Delft, 27 november 2019.

24 K. Kasahara, 'Machiya Today. Concepts and Methods of Renovation Design', in: M.T. van Thoor en S. Stroux (red.), Heritage, History and Design Between East and West. A Close-UP on Kyoto's Urban Fabric, Tu Delft 2018, 53: books. bk.tudelft.nl/index.php/press/catalog/ view/isbn.9789463660280/724/565-1.

DR. M.T. VAN THOOR is architectuurhistoricus en universitair hoofddocent bij de leerstoel Heritage \& Values aan de Technische Universiteit Delft. Van 2011 tot 2020 was zij hoofdredacteur van het Bulletin KNOB.

\title{
AUTHENTICITY, A CREDIBLE CONCEPT?
}

\author{
MARIE-THÉRÈSE VAN THOOR
}

Several of the contributions to this issue on authenticity conclude by asking whether the concept of authenticity is a credible criterion. According to UNESCO's Operational Guidelines for the Implementation of the World Heritage Convention, a monument designated as world heritage possesses 'Outstanding Universal Values' (ouv). It also meets the conditions of integrity and authenticity, at any rate when it comes to cultural heritage. In accordance with The Nara Document on Authenticity (1994), and taking account of global cultural diversity, authenticity can be based on a wide variety of attributes.

Two Dutch World Heritage monuments, the Rietveld
Schröder House (1924) and the Van Nelle Factory (19251931), belong to the architecture of the Modern Movement. In the nomination dossiers for these two heritage buildings authenticity was substantiated in different ways. But in both cases, as has become customary for Modern Movement monuments, 'design authenticity' was deemed of great importance. Has the concept of authenticity been expanded to such an extent that it has ended up being applied arbitrarily? In this author's view, authenticity can most certa inly be a criterion of quality, provided a clear and credible definition is employed within the specific cultural context. 